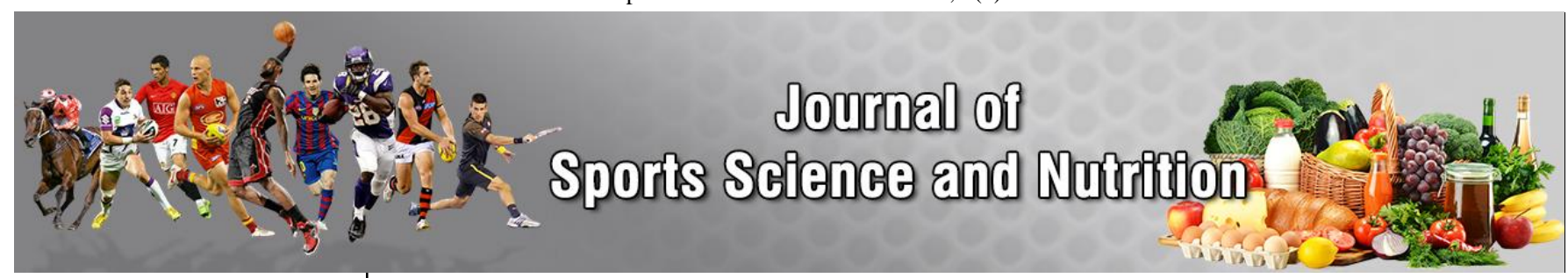

E-ISSN: $2707-7020$ P-ISSN: 2707-7012 JSSN 2020; 1(2): 26-34 Received: 08-11-2020 Accepted: 20-12-2020

\section{Wilson G Sumpio}

Department of Food Science and Nutrition, University of the Philippines, Alonso Hall, Regidor St., University of the Philippines, Diliman, Quezon City, Philippines

\section{Maria Sofia Amarra}

Department of Food Science and Nutrition, University of the Philippines, Alonso Hall, Regidor St., University of the Philippines, Diliman, Quezon City, Philippines
Corresponding Author: Wilson G Sumpio

Department of Food Science and Nutrition, University of the Philippines, Alonso Hall, Regidor St., University of the Philippines, Diliman, Quezon City, Philippines

\section{Vitamin D, Immune function and acute respiratory infection among athletes; A Systematic Review}

\author{
Wilson G Sumpio and Maria Sofia Amarra
}

DOI: https://doi.org/10.33545/27077012.2021.v2.i1a.32

\begin{abstract}
A systematic review of observational studies and randomized controlled trials was conducted to examine the association of vitamin $\mathrm{D}$, acute respiratory infection, and immune markers among athletes; and also to determine the effects of vitamin D supplementation on these same variables. Eleven eligible trials were identified through PubMed, Medline, Embase, Cochrane Central Register of Controlled Trials, and Google scholar search. Five observational studies and six randomized controlled trials with 631 subjects. Published studies were few, more studies showing no effect of vitamin D supplementation on the duration, severity, and frequency of respiratory infection occurrence. A few studies showed that vitamin D supplementation increased salivary IgA and cathelicidin secretion rates. Insufficient evidence exists regarding the association and effects of supplementation on serum vitamin D concentration with respiratory infection and immune biomarkers among athletes.
\end{abstract}

Keywords: vitamin, athletes, acute respiratory tract infection, immune markers

\section{Introduction}

Vitamin D is known for its role in bone-formation, through the regulation of calcium and phosphorus metabolism. It is also involved in the regulation of immune response. Vitamin D receptors (VDRs) are present in immune cells, including $\mathrm{T}$ lymphocytes, B lymphocytes, and antigen presenting cells, indicating its role as a genetic modulator of immunity. These cells express the vitamin D-activating enzyme, 1- $\alpha$-hydroxylase (CYP27B1) signifying that vitamin $\mathrm{D}$ is functionally important to the immune system ${ }^{[1]}$.

Respiratory infection accounts for $35 \%$ to $65 \%$ of non-injury related illness among athletes ${ }^{[2]}$, occurring frequently among those training indoors ${ }^{[3]}$. It has been suggested that overtraining, psychological stress, disrupted sleep patterns, and poor nutrition among athletes can compromise host defence and increase susceptibility to respiratory infections ${ }^{[4]}$. Heavy exercise is believed to be a prominent risk factor for acute respiratory infection (ARI) in athletes ${ }^{[5]}$ and vitamin D might help decrease this risk. A systematic review that included 23 studies with 2,313 athletes showed 56 percent had vitamin D inadequacy and prevalence varied significantly by geographical location ${ }^{[6]}$. At present, it is not clear whether serum vitamin D concentration is associated with incidence of ARI in athletes, and whether vitamin D supplementation can reduce or prevent ARI in this population ${ }^{[7]}$. Owens et al. ${ }^{[8]}$ observed that many athletes now take vitamin D supplements as part of their everyday dietary regimen. However, the authors pointed out the need to clarify "what physiological functions relevant to athletes can be optimized by maintenance of adequate vitamin D status." The present review seeks to examine the best available evidence regarding the association of vitamin D, ARI, and immune function among athletes using findings from published observational studies and randomized controlled trials (RCTs). Specific objectives are to

1) Examine the association of $25(\mathrm{OH}) \mathrm{D}$ serum levels with the following variables:

- Acute respiratory infection (ARI) in terms of

- Number of symptom days (duration of ARI)

- Severity of ARI symptoms

○ Number of symptoms per ARI episode

- Markers of immune function

- Salivary IgA (concentration, secretion rate)

- Pro-inflammatory cytokines (TNF- $\alpha$ ) 
- Anti-microbial peptides (cathelicidin, lactoferrin)

2) Determine the effects of vitamin D supplementation on these same variables.

\section{Materials and methods \\ Search strategy}

Databases searched were PubMed, Medline, Embase, the Cochrane Central Register of Controlled Trials, and Google scholar to identify studies that evaluated vitamin D in athletes and the effects of supplementation on their immune status. Studies published up to January 2021 were included. Search terms used were vitamin D ('vitamin D', 'vitamin', 'cholecalciferol', 'hydroxycholecalciferol', 'calcifediol', 'ergocalciferol', 'calcidiol', 'vitamin D/blood/25hydroxyvitamin D'), immunity ('respiratory infection', 'respiratory tract infection', 'morbidity', 'immune markers', 'immune dysfunctions'), and athletes ('endurance sports', 'sportsman', 'sportswoman', 'active individuals', 'competitors', 'exercise').

The inclusion criteria were: (1) studies done on athletes; (2) observational studies that examined the association of serum vitamin D level with respiratory infection and biomarkers of immune function; (3) randomized controlled trials (RCTs) that examined the effects of vitamin D supplementation on respiratory infection and biomarkers of immune function.

The following data were extracted from the eligible studies: (1) general characteristics (title, first author, journal and year of publication); (2) participants and their characteristics (field of sports, age and gender); (3) type of study (observational, RCTs); (4) vitamin D (intervention doses, routes of administration, and trial duration); (5) relevant independent and dependent variables (serum vitamin D level, serum or salivary immune markers, and symptoms of respiratory infections); (6) method of analysis for each relevant independent and dependent variable; (7) summary results.

Methodological quality was assessed using the Cochrane Collaboration's risk of bias method and the NESR Risk of Bias for Nutrition Observational Studies. Two assessors (WS, SA) evaluated the observational studies and randomized controlled trials (RCTs).

\section{Results}

Our search identified 68 vitamin D studies on ARI and markers of immune function that were assessed for eligibility (figure 1). Of these, 11 studies fulfilled the eligibility criteria. Five observational and six randomized controlled trials were included. All randomized controlled studies administered oral vitamin D3 to participants in the intervention arm given as a daily dose. One of the studies ${ }^{[14]}$ did not have vitamin D as the sole supplement; it included fish oil and protein.

Table 1 presents the characteristics of eligible studies

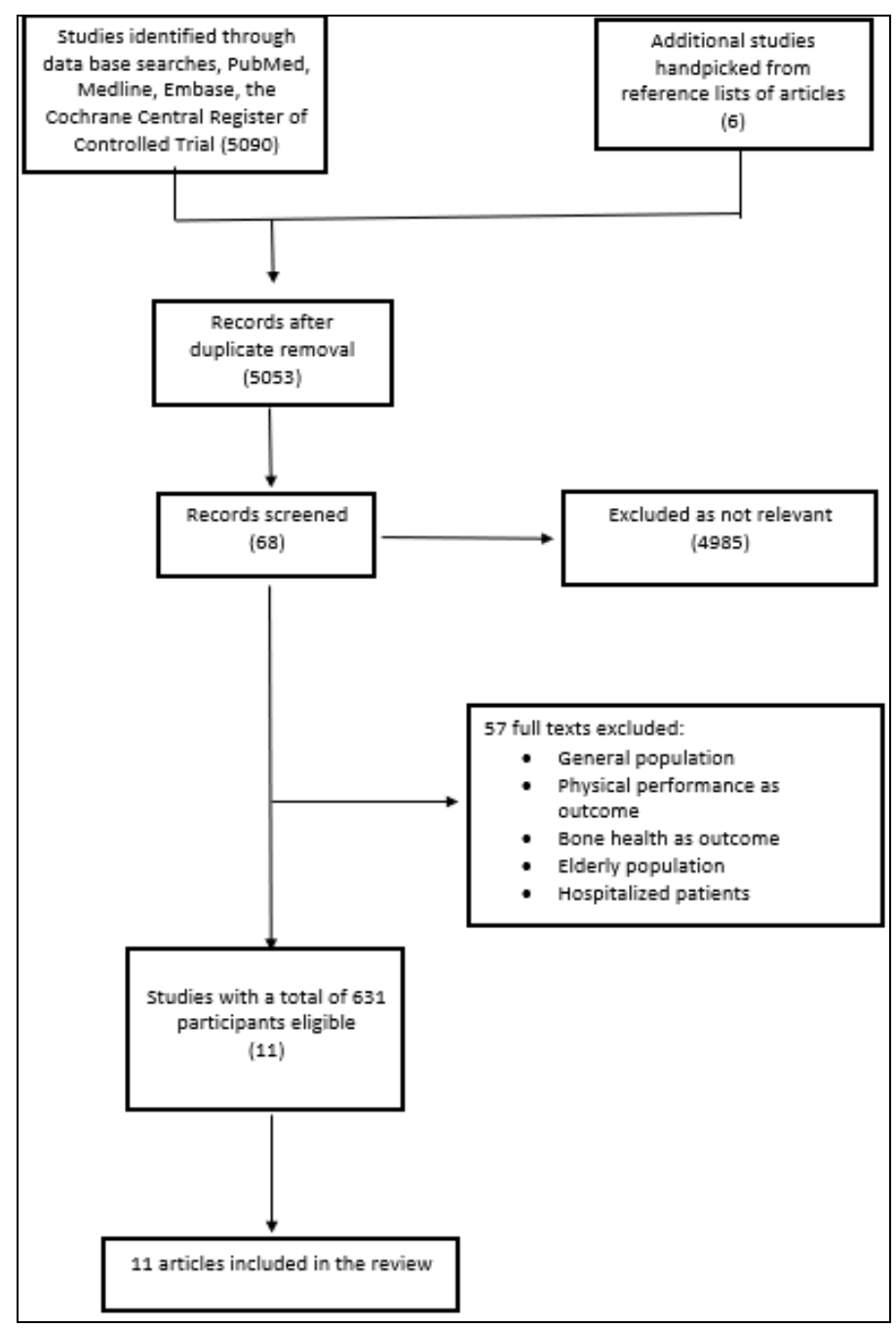

Fig 1: Flow chart for the selection of studies 
Table 1: Characteristics of included studies

\begin{tabular}{|c|c|c|c|c|c|c|}
\hline Author (year) & $\begin{array}{l}\text { No. of } \\
\text { subjects }\end{array}$ & Gender & Age & $\begin{array}{c}\text { Analytical } \\
\text { method to } \\
\text { measure } \\
25(\mathrm{OH}) \mathrm{D}\end{array}$ & $\begin{array}{l}\text { Type of vitamin D } \\
\text { supplement and dose }\end{array}$ & $\begin{array}{l}\text { Baseline serum 25(OH)D of } \\
\text { subjects }\end{array}$ \\
\hline \multicolumn{7}{|l|}{$\begin{array}{c}\text { A. } \begin{array}{c}\text { Observational } \\
\text { studies }\end{array} \\
\end{array}$} \\
\hline He et al. (2013) ${ }^{[15]}$ & 225 & $\begin{array}{l}\text { M } 157 \\
\text { F } 68 \\
\end{array}$ & $\begin{array}{c}21+- \\
3 \mathrm{yr}\end{array}$ & HPLC-MS & N/A & $\begin{array}{c}\text { Optimum/adequate }=62 \% \\
\text { Inadequate/deficient }=48 \%\end{array}$ \\
\hline $\begin{array}{l}\text { Scullion et al. } \\
\quad(2018)^{[16]}\end{array}$ & 53 & $\begin{array}{c}\text { All } \\
\text { female }\end{array}$ & ---- & ---- & N/A & $\begin{array}{l}\text { High vitamin D concentrations } \\
\text { seen in subjects }\end{array}$ \\
\hline $\begin{array}{l}\text { Fikratkerimov et al. } \\
\text { (2019) }{ }^{[17]}\end{array}$ & 40 & $\begin{array}{c}\text { All } \\
\text { male }\end{array}$ & $19-24$ & ELISA & N/A & $\begin{array}{l}83 \% \text { vitamin D insufficient } \\
\text { (15 out of } 18 \text { subjects) }\end{array}$ \\
\hline $\begin{array}{l}\text { Willis et al. (2012) } \\
\text { [18] }\end{array}$ & 19 & $\begin{array}{l}\mathrm{M}=9 \\
\mathrm{~F}=10\end{array}$ & $19-45$ & CLIA & N/A & $\begin{array}{c}\text { Insufficient } / \text { deficient }=53 \% \\
\text { Sufficient }=47 \%\end{array}$ \\
\hline $\begin{array}{c}\text { Barcal et al. (2016) } \\
{[19]}\end{array}$ & 19 & $\begin{array}{c}\text { All } \\
\text { male }\end{array}$ & $>18$ & RIA & N/A & $\begin{array}{c}\text { Insufficient } / \text { deficient }=73.7 \% \\
\text { Sufficient }=26.3 \%\end{array}$ \\
\hline \multicolumn{7}{|l|}{ B. RCTs } \\
\hline Jung et al.(2018) ${ }^{[9]}$ & 25 & $\begin{array}{c}\text { All } \\
\text { male }\end{array}$ & $19-22$ & CLIA & $\begin{array}{c}5000 \text { IU D3/daily for } 4 \\
\text { weeks }\end{array}$ & $\begin{array}{c}\text { Vitamin D insufficient } \\
(31.3 \pm 1.39 \mathrm{nmol} / \mathrm{L})\end{array}$ \\
\hline $\begin{array}{l}\text { Dubnov-Raz et al. } \\
\text { (2014) }\end{array}$ & 55 & ---- & $12-21$ & RIA & $\begin{array}{l}2000 \text { IU D3 daily for } 12 \\
\text { weeks }\end{array}$ & $\begin{array}{l}\text { Vitamin D insufficient } \\
(<30 \mathrm{ng} / \mathrm{ml})\end{array}$ \\
\hline He et al. (2016) ${ }^{[10]}$ & 39 & ---- & $\begin{array}{c}20.4+- \\
1.9\end{array}$ & HPLC-MS & $\begin{array}{c}5000 \text { IU D3/day for } 14 \\
\text { weeks }\end{array}$ & $\begin{array}{l}\text { Sufficient plasma total } 25(\mathrm{OH}) \mathrm{D} \\
\text { concentrations in treatment and } \\
\text { placebo groups before } \\
\text { intervention }\end{array}$ \\
\hline$\underset{[13]}{\text { Mayan } \text { et al. (2015) }}$ & 82 & ---- & $12-16$ & RIA & 2000 IU daily for 12 weeks & $\begin{array}{l}67 \% \text { had vitamin D } \\
\text { insufficiency }\end{array}$ \\
\hline$\underset{[14]}{\text { DaBoit } \text { et al. (2015) }}$ & 42 & $\begin{array}{l}26 \mathrm{M} \\
16 \mathrm{~F}\end{array}$ & $\begin{array}{c}26.8+- \\
4.4\end{array}$ & ---- & $\begin{array}{l}10 \mathrm{ug} \text { D3/ twice a day for } \\
16 \text { weeks (supplement also } \\
\text { contained } 550 \mathrm{mg} \text { DHA, } \\
550 \mathrm{mg} \text { EPA, } 8 \mathrm{~g} \text { whey } \\
\text { protein isolate) }\end{array}$ & ---- \\
\hline $\begin{array}{l}\text { Lewis et al. (2013) } \\
\text { [11] }\end{array}$ & 32 & $\begin{array}{l}19 \mathrm{M} \\
13 \mathrm{~F}\end{array}$ & $>18$ & ---- & 4000 IU daily for 6 months & $\begin{array}{c}\text { No athlete was vitamin D } \\
\text { deficient }\end{array}$ \\
\hline
\end{tabular}

$\mathrm{N} / \mathrm{A}=$ not applicable

---- Unable to obtain information

Risk of bias was assessed using Cochrane Collaboration's risk of bias method and modified NESR Risk of Bias for Nutrition Observational Studies. The 5 observational studies showed low to moderate risk of bias. All of the RCTs exhibited moderate risk of bias. Overall, the quality of included studies was rated as low to moderate.

Table 2 presents the results of studies that examined the association between serum 25(OH)D levels and acute respiratory infections (ARI), and the effects of vitamin D supplementation on ARI. Published studies were few. Favourable findings from observational studies were not consistently borne out by RCTs. Overall, there were more RCTs showing no effect of vitamin D supplementation on the duration of ARI, severity of ARI symptoms, and frequency of ARI occurrence, compared to those showing an effect.

One observational study ${ }^{[15]}$ showed significantly longer duration of symptom days among vitamin D deficient athletes compared to those with optimum/adequate/inadequate vitamin D status. Out of 2 RCTs, one study ${ }^{[14]}$ showed significantly shorter duration of symptom days in the vitamin D supplemented group compared to a placebo group, but information regarding baseline serum vitamin D levels could not be obtained.

One observational study ${ }^{[15]}$ showed significantly greater symptom severity scores among vitamin D deficient athletes. In contrast, two RCTs ${ }^{[12,14]}$ (1 of which was conducted among vitamin D insufficient subjects) consistently showed no difference in reported symptom severity scores between supplemented and unsupplemented groups. One $\mathrm{RCT}^{9}$ among vitamin $\mathrm{D}$ insufficient athletes showed that vitamin D supplemented subjects had significantly lesser total symptoms per ARI episode compared to the placebo group.

Table 2: Vitamin D and acute respiratory infection

\begin{tabular}{|c|c|c|c|c|}
\hline $\begin{array}{c}\text { ARI } \\
\text { characteristic }\end{array}$ & $\begin{array}{c}\text { Author } \\
\text { (year) }\end{array}$ & $\begin{array}{c}\text { Vitamin D variable } \\
\text { observed/ } \\
\text { Supplement given }\end{array}$ & $\begin{array}{c}\text { Adequacy of } \\
\text { baseline serum } \\
\text { 25(OH)D }\end{array}$ & Results \\
\hline $\begin{array}{c}\text { 1. } \begin{array}{c}\text { Number of } \\
\text { symptom } \\
\text { days } \\
\text { (duration) }\end{array} \\
\text { Observational }\end{array}$ He et al. & Vitamin D status & Optimum =11 (5\%) & Number of symptom days was significantly \\
\hline
\end{tabular}




\begin{tabular}{|c|c|c|c|c|}
\hline studies & $(2013)^{15}$ & & $\begin{array}{c}\text { Adequate }(50-99.9 \\
\mathrm{nmol} / \mathrm{L})=128 \\
(57 \%)\end{array}$ & $\begin{array}{c}\text { greater in vitamin D deficient athletes than } \\
\text { those with optimum/adequate/inadequate } \\
\text { vitamin D status }\end{array}$ \\
\hline & & & $\begin{array}{l}\text { Inadequate }(30-49.9 \\
\mathrm{nmol} / \mathrm{L})=68(30 \%)\end{array}$ & Optimum $1(0-6)^{*}$ \\
\hline & & & $\begin{array}{c}\text { Deficient }(<30 \\
\mathrm{nmol} / \mathrm{L})=18(8 \%)\end{array}$ & $\begin{array}{c}\text { Adequate } 4(0-8)^{*} \\
\text { Inadequate } 4(1-8)^{*} \\
\text { Deficient } 9(3-17) \\
P=0.04 \\
\end{array}$ \\
\hline \multirow[t]{7}{*}{ RCTs } & $\begin{array}{l}\text { Da Boit et } \\
\text { al. }(2015) \\
\quad[14]\end{array}$ & $\begin{array}{l}10 \mathrm{ug} \mathrm{D} 3 / \text { twice a day for } 16 \\
\text { weeks (supplement also } \\
\text { contained } 550 \mathrm{mg} \text { DHA, } 550 \\
\text { mg EPA, } 8 \text { g whey protein } \\
\text { isolate) }\end{array}$ & ----- & $\begin{array}{l}\text { Number of symptom days was significantly } \\
\text { shorter in vitamin D-supplemented group } \\
\text { compared to control group } \\
\text { Number of symptom days } \\
\text { (Mean } \pm \text { SD) Vitamin D } \\
\text { supplemented group }= \\
1.72 \pm 1.67 * \\
\text { Control group }=2.79 \pm 1.76 P<0.05\end{array}$ \\
\hline & $\begin{array}{l}\text { Dubnov- } \\
\text { Raz et al. } \\
(2014)^{[12]}\end{array}$ & $\begin{array}{l}2000 \text { IU D3 daily for } 12 \\
\text { weeks }\end{array}$ & $\begin{array}{c}\text { Vitamin D } \\
\text { insufficient }(<30 \\
\mathrm{ng} / \mathrm{ml}) \\
\end{array}$ & $\begin{array}{l}\text { No significant effect of supplementation on } \\
\text { duration of URI }\end{array}$ \\
\hline & & & & $\begin{array}{c}\text { Number of symptom days } \\
(\text { Mean } \pm \text { SD })\end{array}$ \\
\hline & & & & Vitamin D supplemented group $=4.3 \pm 1.6$ \\
\hline & & & & Placebo group $=5.1 \pm 2.2$ \\
\hline & & & & Estimate $(95 \% \mathrm{CI})=-0.9(-2.5,+0.8)$ \\
\hline & & & & Effect in percentage scale $=-17 \%(-50 \%,+7 \%)$ \\
\hline $\begin{array}{l}\text { 2. Severity of } \\
\text { ARI } \\
\text { symptoms }\end{array}$ & & & & \\
\hline \multirow[t]{3}{*}{$\begin{array}{l}\text { Observational } \\
\text { studies }\end{array}$} & $\begin{array}{l}\text { He } \text { et al. } \\
(2013)^{[15]}\end{array}$ & Vitamin D status & $\begin{array}{c}\text { Optimum }=11(5 \%) \\
\text { adequate }(50-99.9 \\
\text { nmol/L) }=128 \\
(57 \%)\end{array}$ & $\begin{array}{c}\text { Vitamin D deficient subjects reported } \\
\text { significantly higher symptom severity scores } \\
\text { than those with optimum/adequate/inadequate } \\
\text { vitamin D status }\end{array}$ \\
\hline & & & $\begin{array}{l}\text { Inadequate }(30-49.9 \\
\mathrm{nmol} / \mathrm{L})=68(30 \%)\end{array}$ & $\begin{array}{c}\text { Symptom severity score } \\
\text { median (IQR) }\end{array}$ \\
\hline & & & $\begin{array}{c}\text { Deficient }(<30 \\
\mathrm{nmol} / \mathrm{L})=18(8 \%)\end{array}$ & $\begin{array}{c}\text { Optimum } 43(38-52)^{*} \\
\text { Adequate } 47(40-69)^{*} \\
\text { Inadequate } 62(46-74)^{*} \\
\text { Deficient } 102(67-199) \\
\text { P value } 0.013 \\
\end{array}$ \\
\hline \multirow[t]{2}{*}{ RCTs } & $\begin{array}{l}\text { Da Boit et } \\
\text { al. }(2015) \\
\quad[14]\end{array}$ & $\begin{array}{c}10 \text { ug D3/ twice a day for } 16 \\
\text { weeks (supplement also } \\
\text { contained } 550 \mathrm{mg} \text { DHA, } 550 \\
\text { mg EPA, } 8 \text { g whey protein } \\
\text { isolate) }\end{array}$ & ----- & $\begin{array}{l}\text { No difference in severity of symptoms between } \\
\text { vitamin D supplemented and control groups }\end{array}$ \\
\hline & $\begin{array}{l}\text { Dubnov- } \\
\text { Raz et al. } \\
(2014)^{[12]}\end{array}$ & $\begin{array}{l}2000 \text { IU D3 daily for } 12 \\
\text { weeks }\end{array}$ & $\begin{array}{c}\text { Vitamin D } \\
\text { insufficient } \\
\text { Serum } 25(\mathrm{OH}) \mathrm{D}<30 \\
\mathrm{ng} / \mathrm{ml}\end{array}$ & $\begin{array}{c}\text { No difference in severity of URI } \\
\text { symptoms between vitamin D } \\
\text { supplemented and control groups } \\
\text { URI severity score Mean }( \pm \text { SD }) \\
\text { Vitamin D supplemented group }=4.7(1.6) \\
\text { Placebo group }=4.4(1.4) \\
\text { Estimate }(95 \% \mathrm{CI})=+0.3(-1.0,+1.6) \\
\text { Effect in } \% \text { scale }=+7 \%(-24 \%,+37 \%)\end{array}$ \\
\hline \multicolumn{5}{|l|}{$\begin{array}{c}\text { Number of } \\
\text { symptoms } \\
\text { per episode }\end{array}$} \\
\hline \multirow[t]{5}{*}{ RCTs } & $\begin{array}{l}\text { Jung et al. } \\
(2018)^{[9]}\end{array}$ & 5000 IU daily for 4 weeks & $\begin{array}{c}\text { Vitamin D } \\
\text { insufficient } \\
(31.3 \pm 1.39 \mathrm{nmol} / \mathrm{L}) \\
\end{array}$ & $\begin{array}{c}\text { Vitamin D supplemented group had } \\
\text { significantly lower total symptoms compared to } \\
\text { placebo group. }\end{array}$ \\
\hline & & & & $\begin{array}{c}\text { Total URTI symptoms } \\
\text { Mean } \pm \text { SD }\end{array}$ \\
\hline & & & & Vitamin D supplemented group $=14.7 \pm 1.64$ \\
\hline & & & & Placebo group $=22.7 \pm 2.27$ \\
\hline & & & & $P$ value $=0.015$ \\
\hline
\end{tabular}

$\mathrm{N} / \mathrm{A}=$ not applicable

---- Unable to obtain information

DHA $=$ docosahexaenoic acid

EPA- eicosapentaenoic acid 
Table 3 shows the results of studies that examined the association between vitamin $\mathrm{D}$ status and markers of immune function and the effects of supplementation on these markers. Immune function markers examined were the following: salivary IgA, cathelicidin, TNF- $\alpha$. A few studies consistently showed that vitamin $\mathrm{D}$ supplementation increased salivary $\operatorname{IgA}$ secretion rate ${ }^{[14,15]}$ and cathelicidin concentration and secretion rates ${ }^{[10,15]}$. Vitamin D (as serum concentration or use as a supplement) did not appear to influence other markers of immune function.

\section{Salivary IgA (sIgA)}

sIgA secretion rate. An observational study [15] showed significantly higher SIgA secretion rates among athletes with optimum vitamin D status compared to those with adequate/inadequate/deficient status. Similarly, one RCT [10] showed significantly increased sIgA secretion among vitamin D supplemented athletes compared to placebo.

\section{Cathelicidin}

Cathelicidin concentration. An observational study [15] showed that athletes with high vitamin D status had significantly higher cathelicidin concentrations compared to those with low vitamin D status. One RCT ${ }^{[10]}$ showed that vitamin D supplementation significantly increased cathelicidin concentrations compared to a placebo group.

Cathelicidin secretion rate. One ${ }^{[10]}$ showed that vitamin D supplementation significantly increased cathelicidin secretion rate compared to placebo.

\section{TNF-o}

Two observational studies $[17,18]$ showed that Vit. D deficient and insufficient athletes had significantly higher levels of TNF- $\alpha$ compared to vit. D sufficient controls. Among elite runners, every $72 \%$ increase in $25(\mathrm{OH}) \mathrm{D}$ concentrations reduced TNF- $\alpha$ concentrations by half ${ }^{[18]}$.

Table 3: Vitamin D and markers of immune function

\begin{tabular}{|c|c|c|c|c|c|c|}
\hline & Author (year) & $\begin{array}{l}\text { Vitamin D } \\
\text { variable } \\
\text { examined/ } \\
\text { supplement }\end{array}$ & $\begin{array}{l}\text { Adequacy of } \\
\text { baseline serum } \\
\text { 25(OH)D }\end{array}$ & \multicolumn{3}{|c|}{ Results } \\
\hline \multicolumn{7}{|l|}{$\begin{array}{c}\text { Salivary } \operatorname{IgA} \\
(\operatorname{sIg} \mathrm{A}) \\
\text { secretion rate }\end{array}$} \\
\hline \multirow[t]{3}{*}{$\begin{array}{l}\text { Observational } \\
\text { studies }\end{array}$} & $\begin{array}{l}\text { He et al. } \\
(2013)^{[15]}\end{array}$ & Vitamin D status & $\begin{array}{c}\text { Optimum }=11(5 \%) \\
\text { Adequate }(50-99.9 \\
\text { nmol/L })=128 \\
(57 \%)\end{array}$ & \multicolumn{3}{|c|}{$\begin{array}{l}\text { Athletes with optimum vitamin D status had } \\
\text { significantly higher median sIgA secretion rate than } \\
\text { those with adequate/inadequate/deficient status }\end{array}$} \\
\hline & & & $\begin{array}{l}\text { Inadequate (30-49.9 } \\
\mathrm{nmol} / \mathrm{L})=68(30 \%)\end{array}$ & \multicolumn{3}{|c|}{ s-IgA secretion rate (ug/min) median (IQR) } \\
\hline & & & $\begin{array}{c}\text { Deficient }(<30 \\
\mathrm{nmol} / \mathrm{L})=18(8 \%)\end{array}$ & \multicolumn{3}{|c|}{$\begin{array}{c}\text { Optimum } 38.7(30.3-48.6) \\
\text { Adequate } 22.9(14.2-36.6)^{*} \\
\text { Inadequate } 19.5(12.7-32.3)^{*} \\
\text { Deficient } 23.6(14.8-32.9)^{*} \\
\text { P }=0.018\end{array}$} \\
\hline \multirow[t]{9}{*}{ RCTs } & $\begin{array}{l}\text { Da Boit et al. } \\
\quad(2015)^{[14]}\end{array}$ & $\begin{array}{l}10 \mathrm{ug} \text { D3/ twice a } \\
\text { day for } 16 \text { weeks } \\
\text { (supplement also } \\
\text { contained } 550 \mathrm{mg} \\
\text { DHA, } 550 \mathrm{mg} \\
\text { EPA, } 8 \mathrm{~g} \text { whey } \\
\text { protein isolate) }\end{array}$ & ----- & \multicolumn{3}{|c|}{$\begin{array}{l}\text { sIgA secretion rate did not differ between treatment } \\
\text { and control groups }\end{array}$} \\
\hline & $\begin{array}{l}\text { He et al. } \\
(2016)^{[10]}\end{array}$ & $\begin{array}{l}5000 \mathrm{IU} \text { D3/day } \\
\text { for } 14 \text { weeks }\end{array}$ & $\begin{array}{l}\text { Sufficient plasma } \\
\text { total } 25(\mathrm{OH}) \mathrm{D} \\
\text { concentrations in } \\
\text { treatment and } \\
\text { placebo groups } \\
\text { before intervention }\end{array}$ & \multicolumn{3}{|c|}{$\begin{array}{l}\text { sIgA secretion rate increased significantly in the } \\
\text { vitamin D supplement group but not in placebo group }\end{array}$} \\
\hline & & & $\begin{array}{c}\text { Median (IQR) } \\
\text { nmol/L } \\
\text { - Treatment group }= \\
54.5(43.2-71.0)\end{array}$ & \multicolumn{3}{|c|}{$\begin{array}{l}\text { Resting sIgA secretion rate } \\
\text { (ug/min) } \\
\text { Median }\end{array}$} \\
\hline & & & $\begin{array}{c}\text { - Placebo group = } \\
57.0(38.7-71.0)\end{array}$ & & $\begin{array}{c}\text { Vitamin D3 } \\
\text { supplemented }\end{array}$ & Placebo \\
\hline & & & & Week 0 & 58.8 & --- \\
\hline & & & & 7 & 87.2 & --- \\
\hline & & & & 14 & 70.5 & --- \\
\hline & & & & $P$ value & 0.026 & NS \\
\hline & & & & Effect size & 0.32 & --- \\
\hline \multicolumn{7}{|l|}{$\begin{array}{l}\text { 2. Cathelicidin } \\
\text { concentration }\end{array}$} \\
\hline Observational & He et al. & Vitamin D status & High vit. D status & thletes with $\mathrm{h}$ & nin D statu & nificantly \\
\hline
\end{tabular}




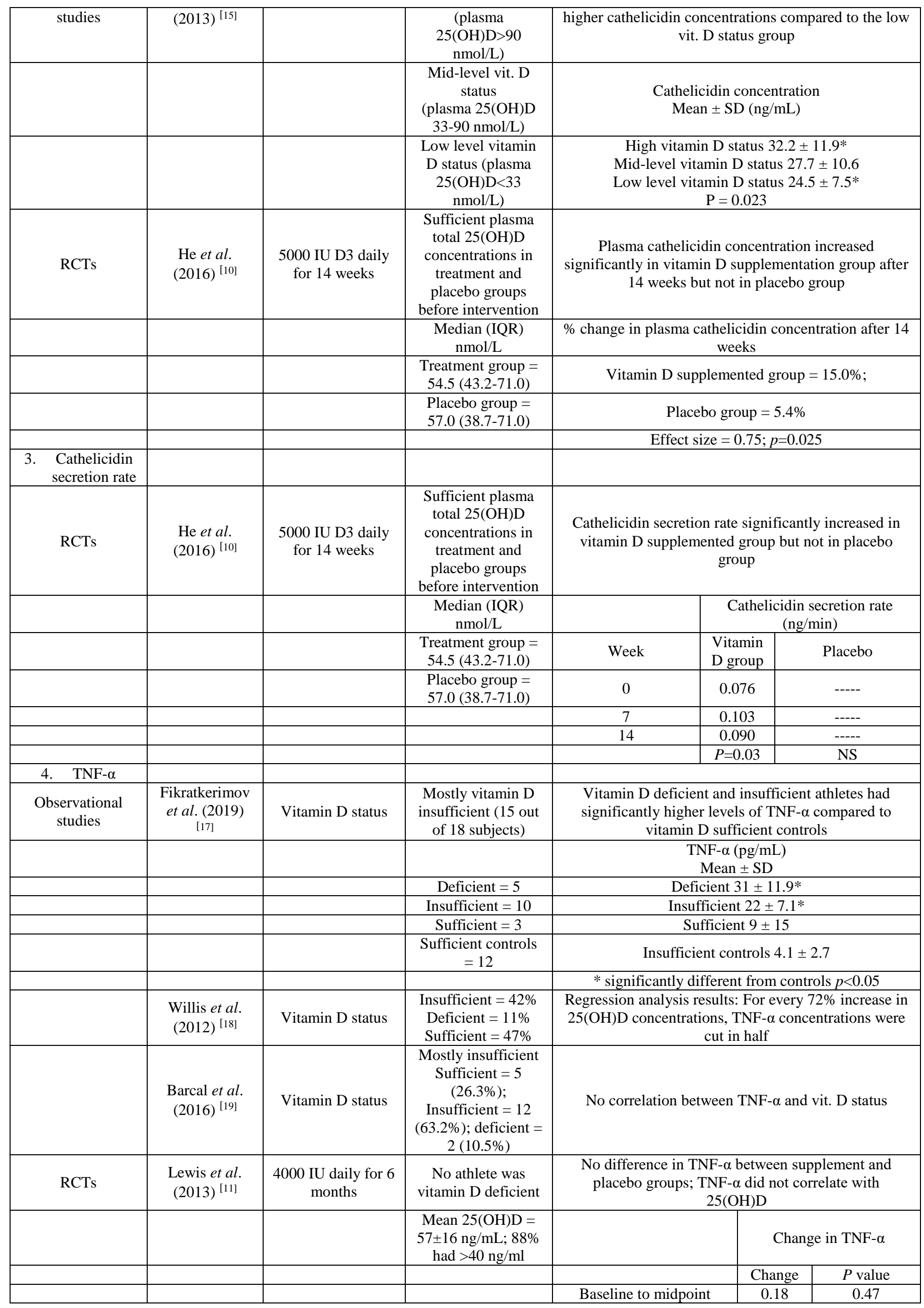




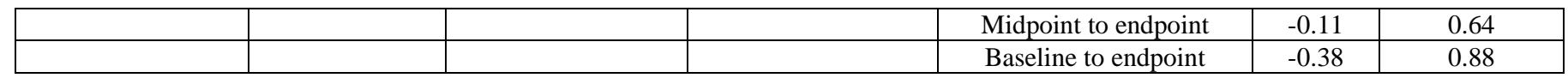

N/A = not applicable

---- Unable to obtain information

DHA = docosahexaenoic acid

EPA- eicosapentaenoic acid

$\mathrm{TNF}=$ tumor necrosis factor

\section{Discussion}

The present study examined the best available evidence regarding the association of serum vitamin D concentration with ARI and markers of immune function among athletes, and the effects of supplementation on these variables. Studies were few (5 observational studies, 6 RCTs). One observational study ${ }^{[15]}$ showed an inverse association between serum $25(\mathrm{OH}) \mathrm{D}$ and ARI, but this was not consistently borne out by RCTs. Overall, there were more RCTs showing no effect of vitamin D supplementation on the duration of ARI, severity of ARI symptoms, and frequency of ARI occurrence, compared to those showing an effect. With respect to markers of immune function, a few studies consistently showed that higher vitamin D serum level or supplementation increased salivary $\operatorname{IgA}$ secretion rate ${ }^{[10,15]}$ as well as cathelicidin concentration and secretion rates ${ }^{[10,15]}$. Vitamin D (as serum concentration or as a supplement) did not appear to influence other markers of immune function that were examined.

The paucity of studies, most of which were rated as moderate quality, and inconsistent findings indicate that insufficient evidence exists regarding the role of vitamin D in reducing or preventing the occurrence of ARI among athletes and in improving markers of immune function. While vitamin D consistently increased salivary IgA and cathelicidin secretion rates which can potentially protect against ARI, more studies using larger samples and athletes of varying ethnicities are needed to confirm these results.

A few meta-analyses of RCTs performed in the general population reported statistically significant protective effects of vitamin $\mathrm{D}$ on development of upper respiratory tract infections ${ }^{20,21}$ while others reported no significant effects. ${ }^{22-}$ 24 Martineau et $a l^{25}$ conducted a systematic review and meta-analysis of 10,933 individual participant data from 25 randomized, double blind, placebo controlled trials of supplementation with vitamin D3 or vitamin D2.

Among patients with inflammatory lung disease, vitamin D supplementation reduced the secretion of inflammatory cytokines involved in the lung inflammatory process and increased the transcription of cathelicidin ${ }^{26}$ While the current review fails to show beneficial effects of vitamin D in reducing or preventing ARIs, findings from a few studies consistently showed that vitamin D increased the levels of some markers of immune function (i.e., salivary $\operatorname{IgA}$ and cathelicidin).

Salivary $\operatorname{IgA}$. The present review suggests that salivary IgA secretion rates increase with increasing vitamin D levels. One of the most promising markers associated with ARI incidence is the level of salivary immunoglobin A, with reduced $\mathrm{S}$-IgA having been demonstrated to be associated with higher ARI incidence in athletic groups. Previous studies showed that among high-performance athletes, a consistent biomarker for identifying and monitoring risk of upper respiratory symptoms is the concentration or excretion rates of salivary $\operatorname{IgA}{ }^{[2]} \operatorname{IgA}$ is recognized as the first line of defense against harmful environmental factors, due to its dominance in the immune system of mucous membranes [27]. According to Gleeson and Pyne ${ }^{2}$, one consensus of studies among elite athletes in different sports is that low levels of salivary $\operatorname{IgA}$ concentration and/or secretion rates, and declining levels over a training period are associated with increased risk of upper respiratory symptoms.

Cathelicidin. The present review shows increased cathelicidin concentration and secretion rates with increased vitamin D levels or supplementation. Cathelicidin is an antimicrobial peptide (AMP) present in neutrophils and epithelial cells ${ }^{[28]}$. AMPs constitute important components of innate immunity, having direct antimicrobial activity and the ability to modulate innate immune responses of the host [28].

Limitations of the present review. The current review shows that very few studies examined the role of vitamin D, ARI, and immune function among athletes. Studies used small sample sizes, varying supplement doses and type of supplement (one study used vitamin D supplement combined with omega-3 fatty acids and protein), different exercise intensities (elite and recreational athletes as subjects), and some studies were conducted among nondeficient subjects. These variations made comparability of results difficult.

Analytical methods used in the reviewed studies to quantify serum 25(OH)D comprised high-pressure liquid chromatography-tandem mass spectrometry $[10,15]$ and immuno-assays $[9,12,13,17-19]$ Isotope dilution liquid chromatography-tandem mass spectrometry (LC-MS/MS) is considered the referent method because it detects both $25(\mathrm{OH}) \mathrm{D}_{2}$ and $25(\mathrm{OH}) \mathrm{D}_{3}$. ${ }^{[23]}$

Technical problems exist regarding the use of $25(\mathrm{OH}) \mathrm{D}$ to diagnose hypovitaminosis $\mathrm{D}$ which may cause misinterpretation of results [29] These include the tight binding of $25(\mathrm{OH}) \mathrm{D}$ to its carrier vitamin $\mathrm{D}$ binding protein (DBP), and the different vitamin D metabolites circulating in the blood ${ }^{[30]}$. Prior to determination, $25(\mathrm{OH}) \mathrm{D}$ needs to be dissociated from its carriers. The dissociation step must be highly efficient to obtain accurate quantification. ${ }^{29}$ Automated immunoassays do not always achieve total dissociation of $25(\mathrm{OH}) \mathrm{D}$ and fail to correctly quantify $25(\mathrm{OH}) \mathrm{D}$, but the issue is not adequately addressed in current clinical guidelines ${ }^{[29]}$ Total circulating $25(\mathrm{OH}) \mathrm{D}$ is the sum of two metabolites: $25(\mathrm{OH}) \mathrm{D}_{2}$ and $25(\mathrm{OH}) \mathrm{D}_{3}$. ${ }^{[30]}$ The ideal method of measurement should equally detect both metabolites.

Standardization of the different assays is key to achieving comparable results across different methods and manufacturers, and is critical for the establishment of common clinical cut-offs for use in routine practice ${ }^{[29]}$.

Analytical issues that still need to be resolved include: 1) refinement of gold-standard methods for quantification of vitamin $\mathrm{D}$ metabolites and assay standardization to make serum values directly comparable between studies and clinical centers $[29,30]$; 2) consideration whether the traditional vitamin D deficiency cut-off, based on the non- 
standardized Diasorin radioimmunoassay, needs to be adjusted for those assays that are VDSP-standardized ${ }^{[29]}$.

Another issue is that overall consensus is lacking with respect to the definitions of vitamin $\mathrm{D}$ deficiency, insufficiency, sufficiency [30] Cut-off levels of 25(OH)D have been recommended by the U.S. Institute of Medicine $(\mathrm{IOM})^{31}$ and the U.S. Endocrine Society (ES) ${ }^{[32]}$.

Romagnoli et al. ${ }^{[30]}$ pointed out that the IOM and ES differences on the definition of 'sufficiency' generated different recommendations about vitamin D intakes.

As a result of these differences, the worldwide prevalence of low vitamin $D$ status varies according to the level of $25(\mathrm{OH}) \mathrm{D}$ utilized to define sufficiency ${ }^{[30,33]}$

In the present review, six studies used ES classification [11, $13,15,17-19]$ only 2 used IOM ${ }^{[9,10]}$ the other 3 made no mention in their articles.

The individual's baseline vitamin D level is important since those with normal or near-normal levels receiving vitamin D supplementation are unlikely to exhibit physiological benefits ${ }^{[33]}$ It has been emphasized that only those with depleted vitamin D stores should receive supplementation to ensure treatment efficiency and minimize risk of adverse events ${ }^{[33}$ In the present review, 7 studies examined the effects of supplementation on deficient subjects $[9,12,13,15,17$ ${ }^{19]}$ while 3 included non-deficient subjects ${ }^{[10,11,16]}$. One had no information ${ }^{[14]}$

\section{Conclusions}

On the basis of this current Review, insufficient evidence exists regarding the association of serum vitamin D concentration with ARI and markers of immune function among athletes, and the effects of supplementation on these variables. A few studies consistently showed that vitamin D increased salivary $\operatorname{IgA}$ secretion rate and cathelicidin concentration and secretion which can potentially protect against ARI. However more studies using larger samples and athletes of varying ethnicities are needed to confirm these results.

Limitations of included studies were: (1) small sample sizes and very few studies examined the role of vitamin D, ARI, and immune function among athletes (2) no standard classification and definition of vitamin D deficiency (3) no standardize methods used to quantify $25(\mathrm{OH}) \mathrm{D}$ (4) gene polymorphisms, sun exposure, skin pigmentation, body composition not included as variables (5) baseline vitamin D level not uniform, some studies were conducted among non-deficient subjects.

Therefore issues that need to be addressed by future investigations are: (1) to increase sample size (2) to use only a single classification and definition for vitamin $\mathrm{D}$ sufficiency (IOM or ES) (3) to use HPLMC-MS to quantify $25(\mathrm{OH}) \mathrm{D}$ (4) to include gene polymorphisms, sun exposure, skin pigmentation among the variables examined.

\section{Acknowledgements}

The authors have no conflicts of interest to declare. No financial support was received for this study. All authors approved the final version of the manuscript and agree to be accountable for all aspects of this work.

\section{References}

1. Baeke F, Takiishi T, Korf H, Gysemans C, Mathieu C. Vitamin D: modulator of the immune system. Curr Opin Pharmacol. 2010;10(4):482-496.
2. Gleeson M, Pyne DB. Respiratory inflammation and infections in high-performance athletes. Immunol Cell Biol. 2016;94(2):124-131.

3. Constantini NW, Arieli R, Chodick G, Dubnov-Raz G. High prevalence of vitamin D insufficiency in athletes and dancers. Clin J Sport Med Off J Can Acad Sport Med. 2010;20(5):368-371.

4. Hellard P, Avalos M, Guimaraes F, Toussaint J-F, Pyne DB. Training-related risk of common illnesses in elite swimmers over a 4 -yr period. Med Sci Sports Exerc. 2015;47(4):698-707.

5. Walsh NP. Nutrition and Athlete Immune Health : New Perspectives on an Old Paradigm. Sport Med. 2019;49(s2):153-168.

6. Farrokhyar F, Tabasinejad R, Dao D et al. Prevalence of vitamin $\mathrm{D}$ inadequacy in athletes: a systematicreview and meta-analysis. Sports Med. 2015;45(3):365378.

7. Hunt JEA, Manders RJF. Effects of vitamin D on health outcomes and sporting performance: Implications for elite and recreational athletes. Published online 2020, 11-24.

8. Owens DJ, Allison R, Close GL. Vitamin D and the Athlete: Current Perspectives and New Challenges. Sport Med. 2018;48(s1):3-16.

9. Jung HC, Seo MW, Lee S, Kim SW, Song JK. Vitamin D3 supplementation reduces the symptoms of upper respiratory tract infection during winter training in vitamin D-insufficient taekwondo athletes: A randomized controlled trial. Int J Environ Res Public Health 2018;15(9).

10. He CS, Fraser WD, Tang J et al. The effect of 14 weeks of vitamin D3 supplementation on antimicrobial peptides and proteins in athletes. $\mathbf{J}$ Sports Sci. 2016;34(1):67-74.

11. Lewis RM, Redzic M, Thomas DT. The effects of season-long vitamin D supplementation on collegiate swimmers and divers. Int $\mathbf{J}$ Sport Nutr Exerc Metab. 2013;23(5):431-440.

12. Dubnov-Raz G, Rinat B, Hemilä H, Choleva L, Cohen AH, Constantini NW. Vitamin D supplementation and upper respiratory tract infections in adolescent swimmers: A randomized controlled trial. Pediatr Exerc Sci. 2015;27(1):113-119.

13. Mayan I, Somech R, Lev A, Cohen AH, Constantini NW, Dubnov-Raz G. Thymus activity, vitamin D, and respiratory infections in adolescent swimmers. Isr Med Assoc J. 2015;17(9):571-575.

14. Da Boit M, Gabriel BM, Gray P, Gray SR. The effect of fish oil, vitamin D and protein on URTI incidence in young active people. Int J Sports Med 2015;36(5):426430.

15. He CS, Handzlik M, Fraser WD, et al. Influence of vitamin D status on respiratory infection incidence and immune function during 4 months of winter training in endurance sport athletes. Exerc Immunol Rev. 2013;19:86-101.

16. Scullion L, Baker D, Healey P, Edwards A, Love T, Black K. No association between vitamin D and acute respiratory tract infections amongst elite New Zealand rugby players and rowers. Int $\mathrm{J}$ Vitam Nutr Res. 2018;88(1-2):8-15.

17. Fikratkerimov, Jamshidumarov, Adyrkhaiev $\mathrm{S}$, et al. Possible associations of $25(\mathrm{OH})$ vitamin D status with 
upper respiratory tract infections morbidity and overtraining syndrome among elite wrestlers. J Phys Educ Sport. 2019;19(6):2177-2184.

18. Larson-Meyer DE, Willis, Smith, Broughton. Vitamin D status and biomarkers of inflammation in runners. Open Access J Sport Med. Published online 2012:35.

19. Barcal JN, Thomas JT, Hollis BW, Austin KJ, Alexander BM, Larson-Meyer DE. Vitamin D and weight cycling: Impact on injury, illness, and inflammation in collegiate wrestlers. Nutrients. 2016;8(12):1-15.

20. Bergman P, Lindh AU, Björkhem-Bergman L, Lindh JD. Vitamin D and Respiratory Tract Infections: A Systematic Review and Meta-Analysis of Randomized Controlled Trials. PLoS One. 2013;8(6):e65835.

21. Charan J, Goyal JP, Saxena D, Yadav P. Vitamin D for prevention of respiratory tract infections: A systematic review and meta-analysis. J Pharmacol Pharmacother. 2012;3(4):300-303.

22. Mao S, Huang S. Vitamin D supplementation and risk of respiratory tract infections: a meta-analysis of randomized controlled trials. Scand $\mathrm{J}$ Infect Dis. 2013;45(9):696-702.

23. Xiao L, Xing C, Yang Z, et al. Systematic Review with Meta Analysis Vitamin D supplementation for the prevention of childhood acute respiratory infections : a systematic review of randomised controlled trials. 2015;25:1026-1034.

24. Vuichard Gysin D, Dao D, Gysin CM, Lytvyn L, Loeb M. Effect of Vitamin D3 Supplementation on Respiratory Tract Infections in Healthy Individuals: A Systematic Review and Meta-Analysis of Randomized Controlled Trials. PLoS One. 2016;11(9):e0162996.

25. Martineau AR, Jolliffe DA, Hooper RL, et al. Vitamin $\mathrm{D}$ supplementation to prevent acute respiratory tract infections: systematic review and meta-analysis of individual participant data. BMJ. 2017;356:i6583.

26. Amrein K, Scherkl M, Hoffmann M, et al. Vitamin D de fi ciency 2.0: an update on the current status worldwide. Eur J Clin Nutr. Published online 2020, 1498-1513.

27. Trochimiak T, Hübner-Woźniak E. Effect of exercise on the level of immunoglobulin a in saliva. Biol Sport. 2012;29(4):255-261.

28. Mahlapuu M, Håkansson J, Ringstad L, Björn C. Antimicrobial Peptides: An Emerging Category of Therapeutic Agents. Front Cell Infect Microbiol. 2016;6:194.

29. Herrmann M, Farrell C-JL, Pusceddu I, FabregatCabello N, Cavalier E. Assessment of vitamin D status - a changing landscape. Clin Chem Lab Med. 2017;55(1):3-26.

30. Romagnoli E, Pepe J, Piemonte S, Cipriani C, Minisola $\mathrm{S}$. Value and limitations of assessing vitamin D nutritional status and advised levels of vitamin D supplementation. Eur J Endocrinol. 2013;169(4):59-69.

31. Ross AC, Taylor CL, Yaktine AL, Del Valle HB, eds. Institute of Medicine (US) Committee to Review Dietary Reference Intakes for Vitamin D and Calcium 2011.

32. Holick MF, Binkley NC, Bischoff-Ferrari HA et al. Evaluation, treatment, and prevention of vitamin D deficiency: an Endocrine Society clinical practice guideline. J Clin Endocrinol Metab 2011;96(7):19111930.

33. Stokes CS, Lammert F. Vitamin D supplementation: less controversy, more guidance needed. F1000Research 2016, 5. 